\title{
An Emerging Awareness of Generation Z Students for Higher Education Professors $\odot$
}

\author{
Catherine Giunta, Ph.D. \\ Professor-Business \\ Seton Hill University \\ Greensburg, PA, United States
}

\begin{abstract}
Generation Z, sometimes referred to as the iGeneration by demographers, marketers, and psychologists are a point of research by business professionals. However, little work has been done by academicians to research these students' perceptions on various issues in a college setting. This study investigated Generation $Z$ college students' views regarding trust, use of social media, and related issues. The variables studied relate to current literature and key indicators representative of this generation. College students were the targeted participants. Students were surveyed in business courses after permission of the instructor was obtained. Subsequent interviews of faculty have begun. Quantitative surveying of faculty has been initiated. The findings indicate a group with high expectations for trust in others and with dependency on social media. The ramifications for professors will be discussed.
\end{abstract}

\section{INTRODUCTION}

Generation Z, sometimes referred to as the iGeneration by demographers, marketers, and psychologists are a point of research by business professionals. However, little work has been done by academicians to research these students' perceptions on various issues in a college setting.

This multi-phase study investigated Generation Z college students' views regarding trust, use of social media, and related issues. The variables studied relate to current literature and key indicators representative of this generation. College students were the targeted participants. Students were surveyed in business courses after permission of the instructor was obtained. Phase 2 includes subsequent interviews of faculty and staff that interact with this age group; this phase has begun.

This research studied if this sample of Generation $\mathrm{Z}$ expects trust and truthfulness from those with whom they interact. How much they connect via social media was an area of questioning. Furthermore, if they perceive themselves as dependent upon this technology was determined.

\section{CHARACTERISTICS OF GENERATION Z}

While research is limited on this generation, many consider the Gen $\mathrm{Z}$ birth period between 1994 and 2004 [ending 2010, Renfro, 2012] (Mueller, 2011). It is estimated that Gen Z are 23 million individuals. Interestingly, given their birth years, many of the members of this generation also overlap the latter Millennial years. This observation is useful, yet somewhat deceiving as you will read, when studying Generation Z. Note: in recent years (2013 on) marketers focused and wrote about Gen Zers who, in particular, were 14-19; therefore they're young and their views may change as they age.

Gen Z is also called Generation I, Generation Next, New Silent Generation, Homelander Generation, Vista Generation, Internet Generation, iGeneration, Generation Now, Computer 
Generation, Generation M (Millennium or Multi Task), Millennials, Google Generation, Generation Q (Quiet), Net Gen or Net Natives (Generation Z-The iGeneration). They are so comfortable -- perhaps dependent on technology -- that they are often termed Digital Natives. Slavin (2014) describes the characteristics of Gen Z: Born in the digital world and use technology to connect with-not escape from-each other and the world; Holistic Connections: they want to be engaged in experiences that take them out of their comfort zone; they build a community by wanting to be heard, actively participating in what is around them and leading. They share stories and may not listen to those older because members of that age groups are perceived as those who have made mistakes. Members of Generation Z create movements and trends in marketing (Slavin, 2014), and may carry the realization of that impact into the classroom.

Thomas (2000) describes this group as somewhat outspoken, idealistic and action-oriented. Like the Millennials (Generation Y), they are optimistic. They display introspective intellectualism. Furthermore, being tech-savvy, and having no memory of pre-Internet history, they believe computer technology is commonplace. They see social networking as the norm and are facile with various social media sites and networking platforms. Therefore, they are members of various 'Net communities. As new technologies emerge, they may be among the first to use them and to become immersed in them. Since they were so active in electronic communities as they grew up, Mueller (2011) notes that they have little concern for privacy and no problem sharing even the most intimate details of their lives with virtual strangers. They have short attention spans (Micoleta, 2012). They are frequent bloggers, or "Vloggers" (video bloggers) (Benhamou, 2015) and enjoy digital publishing (Lyon, 2010). Correspondingly, similar to Generation Y, Generation Z are very collaborative and creative. They prefer a flat organization to a hierarchy at work (Benhamou, 2015). They are comfortable, and they believe capable at multi-tasking. There is concern that they may not perform well in areas such as public speaking, which is an essential business skill set.

Gen $\mathrm{Z}$ is, though, in many ways, different from their older counterparts in the Millennial Generation. For example,

"Generation Z is growing up in a time of complexity... Generation Z doesn't want to be tracked, preferring Snapchat, Secret, or Whisper to communicate...Generation Z wants to co-create, live stream and help to make up the activity as they participate...Generation $\mathrm{Z}$ has an attention span of 8 seconds. ..Generation Z prefers communicating through images, icons and symbols rather than texts...They multitask on five screens [a smartphone, TV, laptop, desktop, iPod (Glum, 2015)], not one or two. They experience FOMO: the "Fear Of Missing Out." ... They plan to get educated and start working earlier, but will be 'school hackers' " (Elmore, 2014). One report noted that $40 \%$ of them expect to work for themselves at some point (compared with $10 \%$ of the older Millennials). Comparable to their older counterparts, they prefer integration of practical experiences within their majors (StatsWatch, 2015).

It's essential to remember that the individual members of Gen $\mathrm{Z}$ have unique personalities and backgrounds. They are inundated with homework, extracurricular activities, and other social and family commitments (Crappell, 2013). This is similar to their older Millennial counterparts.

\section{INFLUENCERS OF GENERATION Z}

Generation $\mathrm{Z}$ is the first generation in the United States to be born with complete electronic technology. Their formative years have been spent using Internet platforms. They were born with PCs, mobile phones, gaming devices, MP3 players and the Internet. Social media, such as Facebook, is commonplace to them (Lyon, 2010). Generation Z grew up with touch-screens. 
Their phones have always been "smart" (Elmore, 2014). This social networking has provided many virtual friends who they may have never met face-to-face. Their paradigm of who constitutes colleagues is vastly different from that of Generation X and those older. Video sharing platforms, including YouTube are frequently accessed by this group. They have seen the emergence of high-tech cell phones, which are termed "smart phones" for their relatively extensive capabilities. Interestingly, though, they prefer anonymous, fast-erasing social media platforms (Glum, 2015). They believe they email, text and use computers without any problems, although Medina (2008) has found that the multi-tasking is inefficient.

Despite the fact that this generation is technologically sophisticated for their age, they are also members of the age groups that have seen less outdoor activity, more sedentary life styles, and corresponding health issues. Furthermore, due to the rapid movement of technologic communication, they expect instant-gratification (Crappell, 2013; Banhamou, 2015). Familiar with anonymous criticism, they have and expect to continue to speak with "an audience" (Generation Z, 2008) in the public sphere. Additionally, they are capable of finding information from multiple sources, including YouTube when writing research papers (Glum, 2015). Furthermore, this generation is the most diverse and multicultural of any in the United States with 55\% Caucasian, 24\% Hispanic, 14\% African-American, and 4\% Asian. They have been described as responding to innovative thinking and self-direction. They are very transparent online, and they prefer a 2-way conversation when online. They are open-minded and adaptable (Bernstein, 2015).

Additionally relevant to educators, they have been described as "independent, stubborn, pragmatic, and always in a rush". They speak using many acronyms unique to their generation. They are "self-educators", in that they learn new things through self-help videos on YouTube. According to a study by Sparks and Honey, the average Gen Z-er spends more than three (3) hours per days in front of a screen. They skim-read rather than reading thoroughly. When asked for a reaction to the word "business" responses include "complicated", "brutal", and " a jungle" (Benhamou, 2015). This latter point may be particularly disconcerting to those who teach business. According to Williams (2015), their pragmatism leads them to want to see themselves as in control and are very focused on "sensible" careers.

\section{METHOD}

This study investigated Generations Z college students' views regarding trust, use of social media, and related issues. The variables studied relate to current literature and key indicators representative of this generation. Students were surveyed in business courses after permission of the instructor was attained. The student survey questions were the basis for the subsequent face-to-face interviews with faculty, and for faculty surveys. Those interviewed face-to-face are in the very early stage.

The study employed a web based questionnaire for quantitative methods. The questionnaire included multiple choice and fill-in-the blank question types. The survey was pre-tested by a small group of faculty. The instrument was then administered to undergraduate students in the targeted courses. During Stage 1, which is reported in this paper, a sample of 81 students was the student participants group. The university in which the research was conducted is a small private institution. In Stage 2, the research was expanded to include faculty from business and other disciplines that were interviewed and surveyed. This stage will also include administrative staff interviews in the future. The web-based faculty interview questions are based upon the student survey questions and ask professors their perceptions of Generation $\mathrm{Z}$. A group of 20 professors were surveyed online. Faculty are surveyed to determine if their 
views of students' responses are accurate compared to actual student research's findings. Stage three may then be conducted in other academic higher education colleges and universities.

\section{FINDINGS}

Many members of Gen Z are familiar with just the "tip" of the Internet iceberg and are unfamiliar with electronic resources, such as commercial subscription databases. They demonstrate an overreliance on Google as the first and best choice to find answers. They do not have the meta-cognitive skills to know when to stop using Google and other search tools and to try a different information search strategy. Further, these young searchers often use Google carelessly to determine or measure the significance of a topic or individual, thereby leading to faulty conclusions (Geck, 2006, Are these teenagers Internet experts or novices?, para. 6).They are not information literate (Geek, 2006). This is a major concern because college students need to be information literate in the library with academic sources.

As mentioned previously, literature suggests that Generation $\mathrm{Z}$ members are typically connected with others. This manuscripts' research of college Gen Zers supports that earlier research, as shown below in Figures 1 and 2. As Renfro (2012) noted, "Gen Zs are always connected in a near seamless cloud-based world of friends, data, and entertainment."
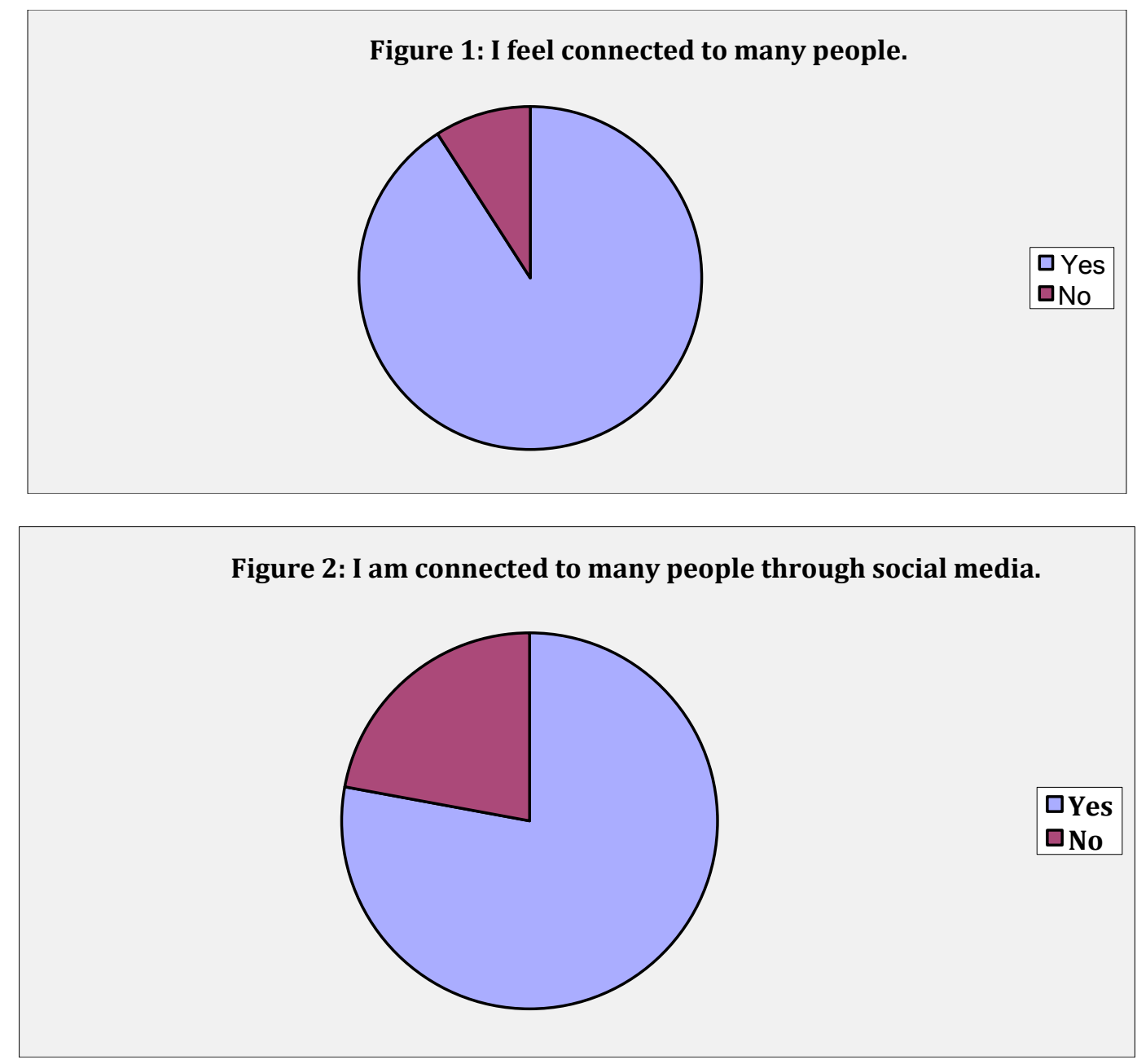

Furthermore, general interest literature about this generation suggests that they value trusting other people. This study supports that premise for college freshmen (See below.) Furthermore, the researcher all respondents noted that trust in someone else is important to them. The vast majority noted that this aspect was very important to them. 

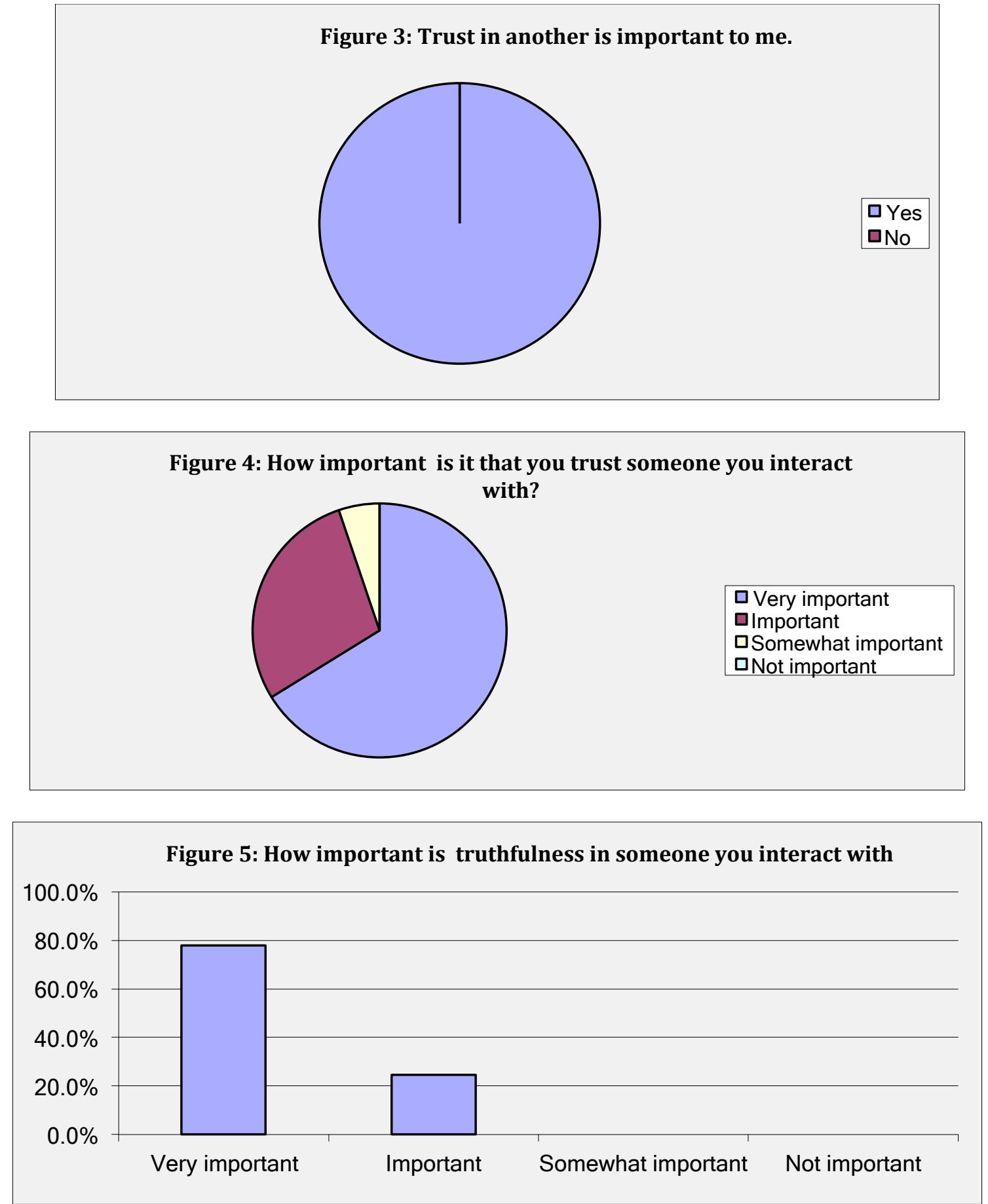

It has been questioned that since this generation relies so much upon others, that they may lack the adaptability and flexibility needed in the $21^{\text {st }}$ century business world. This research does not support this concern. This group of Generation $\mathrm{Z}$ believes they are very adaptable and flexible to new ideas. (Please see Figures 6 and 7 below for their perception of their adaptability.) These skills will be essential in business careers, especially in the fast- changing business discipline. This researcher's findings support Renfro's $(2012, a)$ view that, " They are flexible in nature and expect flexibility from institutions". 
Figure 6: How adaptable to new ideas or ways of doing things are

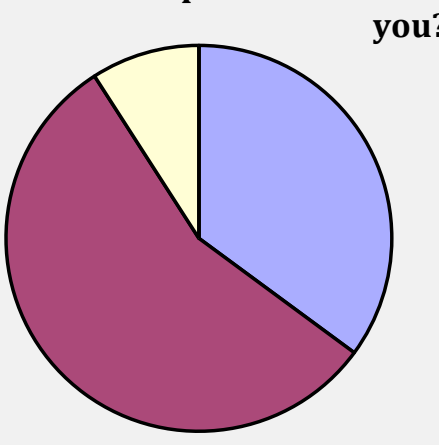

$\square$ Very adaptable

$\square$ Adaptable

$\square$ Somewhat adaptable

$\square$ Not adaptable

Figure 7: How flexible to new ideas or ways of doing things are you?

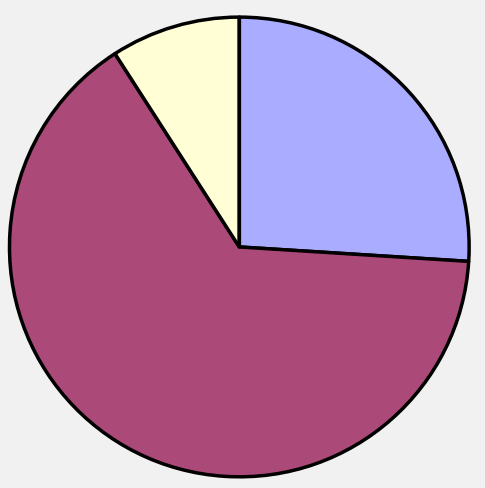

$\square$ Very flexible

口Flexible

$\square$ Somewhat flexible

$\square$ Not flexible

Since GenZ is the most diverse generation in the United States to date, it is expected that they are accepting of diverse populations. Williams (2015) states that between 2000 and 2010, the United States' Hispanic population grew four times faster than the rate of the total population; that Americans self-identifying as biracial of black and white grew 134 percent; those biracial of Asian descent and white grew 87 percent (para. 20). This research supports that view, as seen in Figure 8. Higginbottom (2013) found that Gen Z expects that diversity and equality will be the norm in the workplace.

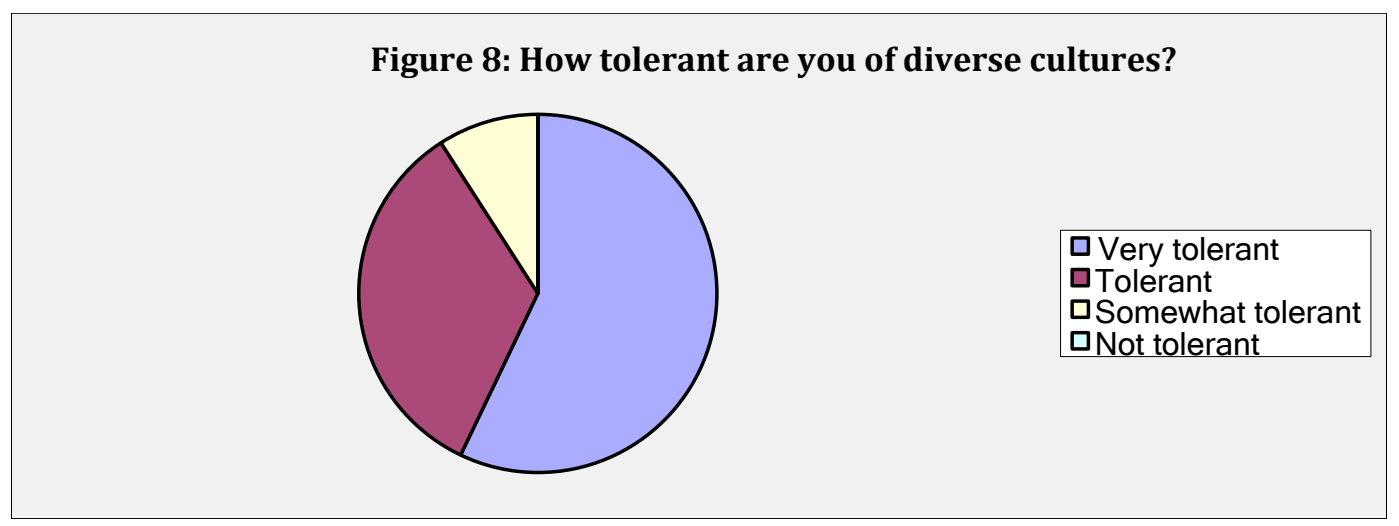

One characteristic of Generation $\mathrm{Z}$ is their active use of technology. The researcher asked the students to rank how comfortable they are with technology. In the study, the vast majority "strongly agreed" with the statement "I am comfortable with technology". Additionally, many of the respondents "agreed" with the statement. Only a small percentage slightly disagreed 
with the statement. None of the students disagreed. Furthermore, the vast majority of students said they are dependent upon technology. (Please see below.)
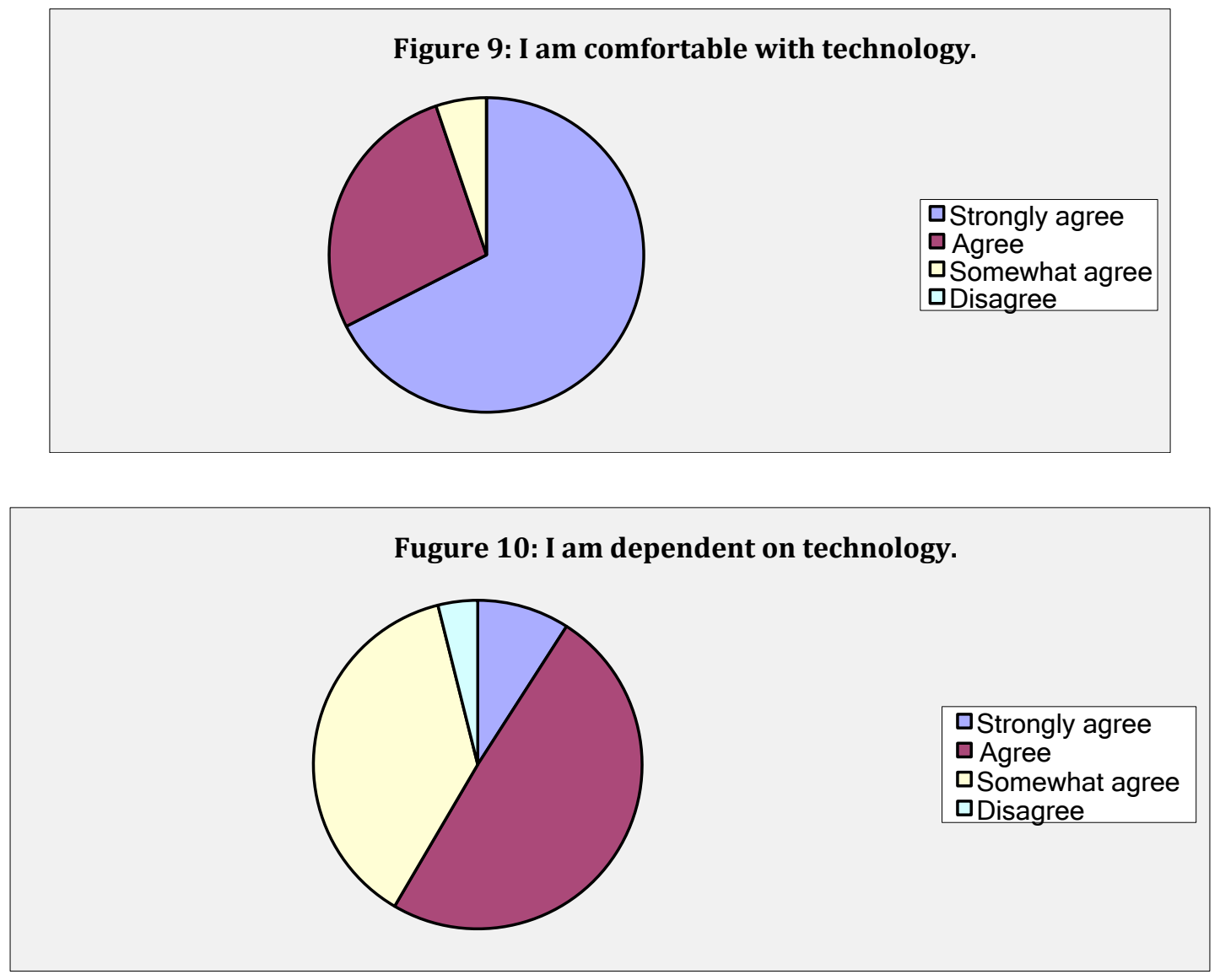

The researcher next investigated the students' use of technology. Abramovich (2015) cites Ad Week information that "thirty-three percent of Gen Zers watch lessons online, 20\% read textbooks on tablets, and 32\% work with classmates online" (para. 6). (Fudin (2012) states, "They have a positive attitude towards technology and are not afraid to try new things. Because they're comfortable exploring the Internet, they're more connected to the world than previous generations. When they're curious about a subject, they'll often research it online." The findings detailed here may help to explain why this attitude may exist.

The majority of surveyed students spend 2-7 hours per day online. The university in which the research was conducted has been recognized as a technology-advanced 4-year institution, and that may explain why these results are more hours than Banhamou (2015) found. For example, this researcher's university was the first to provide faculty and every full-time student an iPad in 2010. New full-time students (most are Generation Z) received an iPad with retina display in 2012 (in addition to the MacBook Pro for all of incoming freshmen.) The university is an Apple Distinguished Program, which is a designation reserved for programs that are recognized centers of educational excellence and leadership (Seton Hill University main website page). That academic environment may have influenced the students' responses. As shown below, the students typically reported spending at least 2-3 hours/week online as part of class work (34\% of respondents). Furthermore, this steady use of technology continues on class-related assignments outside of the class sessions, with $50.7 \%$ stating $2-5$ hours outside of class (Please see charts below.) 
Figure 11: How much time do you spend online during a typical

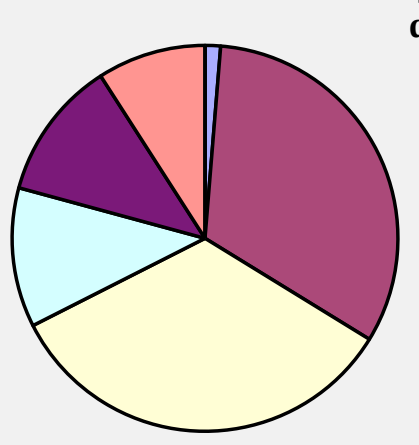
day?

Figure 12: How much time do you spend online during class time in a typical week?

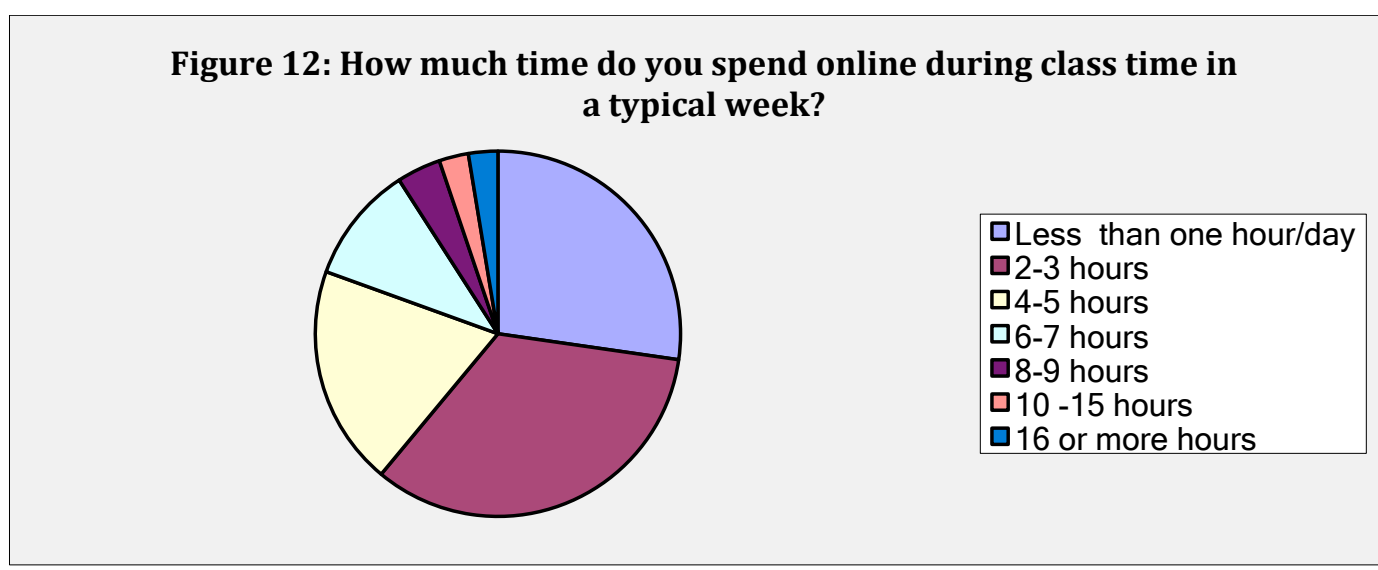

L2-3 hours

प4-5 hours

व6-7 hours

8-9 hours

$\square 10$-15 hours

$\square 16$ or more hours

Figure 13: How much time do you spend online outside of classes during a typical week?

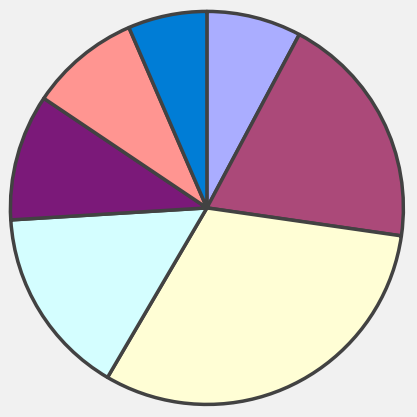

पless than one hour/day

$\square 2-3$ hours

प4-5 hours

口6-7 hours

8-9 hours

口10-15 hours

$\square 16$ or more hours

Generation $\mathrm{Z}$ is very close to their parents. However, it has been stated that parents tend to build too much "easy-to-get self-esteem" in their Gen Z children. This high self-esteem along with easy-to-use digital tools leads the Gen Zs to think they can do anything (Renfro, 2012, a). Correspondingly, Slavin (2014) noted that Gen Zers want to be heard and want to actively participate in what's happening in the world. They want to make changes for what they perceive as mistakes made by the older generations. As part of their mindset, this research has found that most of the students feel connected to many people. 
Figure 14: Do you believe Generation $Z$ college students feel connected to many people?

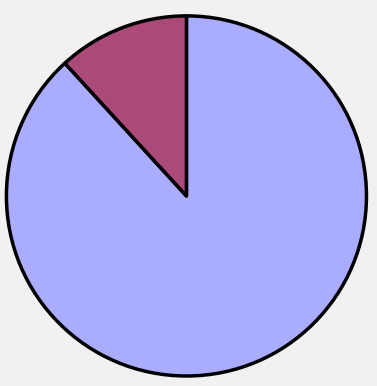

The researcher investigated what tools students use to virtually connect with others. As shown by the chart below, texting was the most preferred method of connecting with others, followed by social networks, and then, Facebook. An open-ended question on the survey asked students to note other ways they prefer to connect virtually with others. If the reader doesn't recognize all of the social media platforms stated, one needs to realize that this generation is currently using some social networking sites that are not known to older generations. This fact may become a class management issue if professors do not know what platforms to monitor.

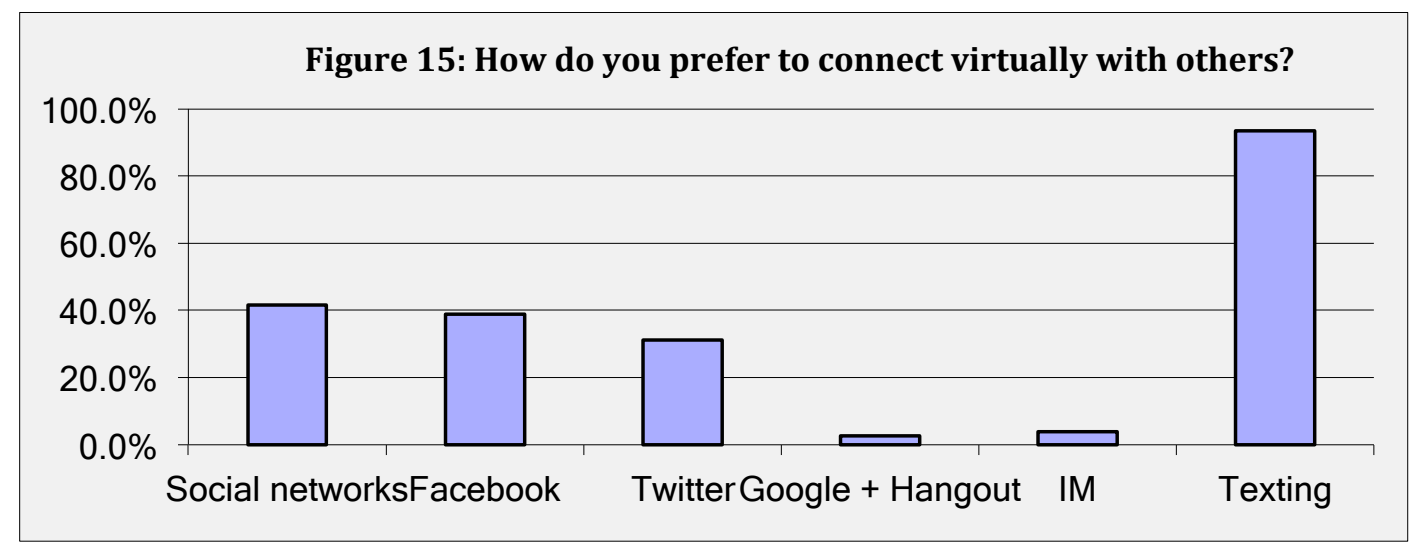

FACULTY PERCEPTIONS

In Phase 2 of this study, 20 faculty were surveyed online $(17$ completed the entire survey. Some faculty didn't believe they were knowledgeable enough of this group of students to complete all questions.) and seven different faculty were interviewed face-to-face. More faculty from the online group will be interviewed face-to-face. Their responses correspond to the students' responses, indicating a generally accurate understanding of this group of students.

When asked if Gen Z students connect to many people through social media, all online surveys stated yes. (See chart below.) Stone (2010) reported that a survey in 2009 by Pew showed that teenagers are more likely to send instant messages than slightly older 20-somethings (68 percent versus 59 percent) and to play online games (78 percent versus 50 percent). Larry Rosen, cited in Stone, has said that younger Gen Zers may spend considerably more time texting than talking on the phone, paying less attention to television than the older group, and tending to communicate more over instant-messenger networks. Higginbottom (2013) has stated that "They are complete digital natives and cannot function without communicating through social media". 
Figure 16: Do you believe the Generation $\mathrm{Z}$ college students connect to many people through social media?

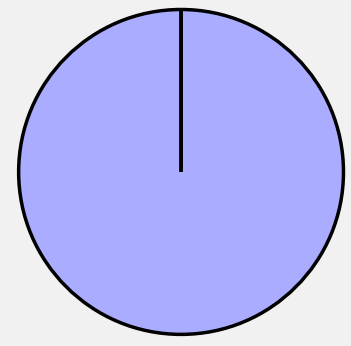

As evidenced by this research about college Generation $\mathrm{Z}$ members, they bring a high expectation for trust in others to their college experience. Professors surveyed agree with this attitude. (See below.) Although professors are accustomed to establishing some level of camaraderie with students, the "trust factor" may not have been deemed a high-priority consideration. Most students in the survey noted that they have good-to-very good teacher-tostudent relationships. Realizing how important this factor is to this group of students, faculty may need to ensure the relationship is not only professional, but also "trustworthy". Consistency of grading, equitable treatment of students, and predictable reactions by the professor will be key. How this generation defines "trust" and how they expect trust to be established in their professor-student interactions will become more evident as their numbers grow in universities. Correspondingly, professors will also want to prepare students to display the trust they expect of others.

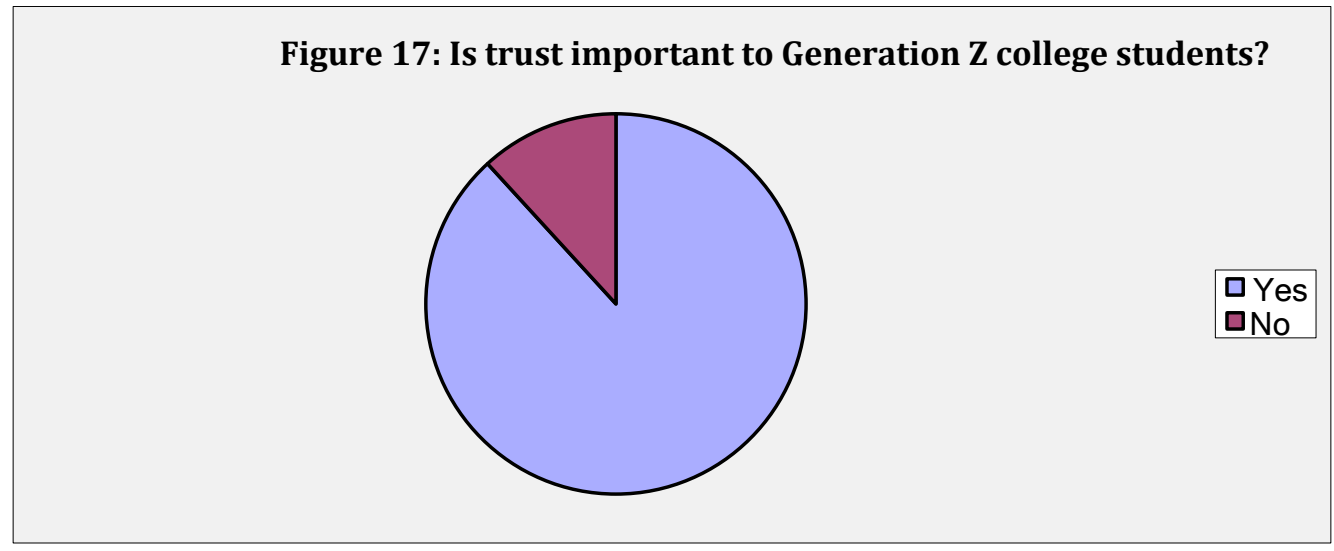

Renfro (2012,a) warns that other generations must deal with Gen Z's' changing (or lack of) interpersonal skills that are driven by advancing technologies. Generation Z prefers a flat organization to a hierarchy at work (Benhamou, 2015). How this will translate into the class is still evolving. Most surveyed faculty in this study believe it's important for these students to have an older academic associate whom they can trust. (See Figure 18.) Although an academic associate may not be a friend, $92 \%$ of the students responded that they have an older friend whom they can trust. 
Figure 18: Do you believe that Generation $\mathrm{Z}$ college students have an older academic associate that he/she can trust.

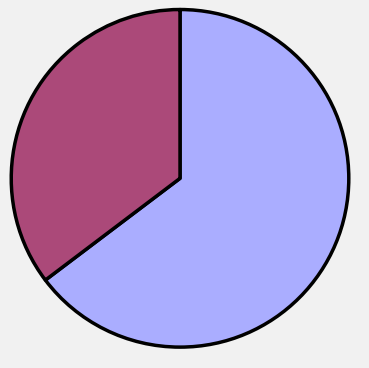

Contrasting the fact that $88 \%$ of the online surveyed faculty believe that Generation $\mathrm{Z}$ college students think truthfulness in someone with whom they interact is very important-toimportant (See Figure 19.), attention has been paid to the concerns about Generation Y's possible tendencies for classroom cheating. If Generation $\mathrm{Z}$ members are more transparent than older Millennials, will this influence their perception of "sharing" work with others and lead to more cheating ? Renfro $(2012$, b) discusses the impact of gaming on this generation, including on their possible views towards what constitutes "cheating". His discussion includes that, "Gamers are rewarded along the way. They get instant feedback....They work in a collaborative environment. The gaming environment is immersive and visual....Cheats allow gamers to advance when they are stuck or need help". This gaming mindset may blur the perception of the possible severity of "cheating" consequences. Will Gen Z's extensive use of technology impact their transparency and therefore their view of what does, and what does not constitute cheating, per se?

Figure 19: How important do you think Generation $\mathrm{Z}$ college students think truthfulness in someone with whom they interact is?

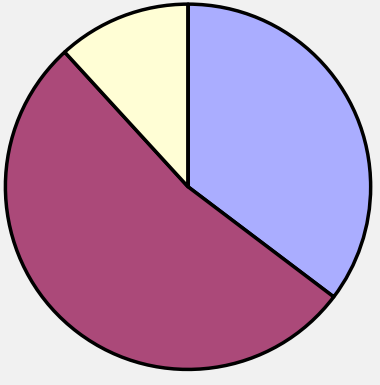

$\square$ Very important

口Important

口Somewhat important

口Not important

Generation Z, like Generation Y, uses social media extensively. Since Generation Z started using this technology earlier than Generation Y, have their socialization processes been impacted to the point that their self-reported "dependency" on technology will become a significant classroom management issues? Since their sense of "privacy" is viewed quite differently from that of their professors from Generation X and older, will Generation Z students respect other students' privacy regarding remarks shared in the classroom and on electronic course sites? If they are working on an assignment, including primary research, that involves confidentiality, will Generation Z students appreciate the need to follow Institutional Review Board and the course assignment's privacy requirements? If this is a concern for a professor, what steps can be taken to develop this competency in the students? For example, students need to sign confidentiality agreements for some assignments, and the professor has to define confidentiality, and to stress the importance of that action. 


\section{IMPLICATIONS FOR BUSINESS PROFESSORS}

As many professors may attest, the attention span of Gen Z is short. Furthermore, for Gen Zers to focus on a single task for any length of time can seem arduous. Setting goals at several levels can prepare students for more difficult tasks. Rather than assigning work in time slots, assign specific tasks and/or weekly goals. Success can motivate; therefore professors want to consider projects that allow for students to experience regular success (Crappell, 2013). Simulations can be very effective for this generation. More than half of these students want experiential learning, and 89 percent of these students, in a recent study, rated higher education's value as "'very high'" and as a means to secure a good job. This love of learning may facilitate them adapting to the new challenges and expectations that they'll find in higher education classrooms (para. 2,and 5). Educators will need to teach students how to analyze, interpret, and utilize ever-changing content and information, rather than educating students on how to collect information (Dillon, 2007). Simulations can facilitate the development of these cognitive skills.

Garff (2011) noted that virtual teaming at the workplace will increase. A recent survey of America's largest companies found that executives are concerned about a "lack of trustbuilding opportunities" in those virtual settings (p. 22). The growth of this workplace practice creates a potentially paradoxical situation for Generation $\mathrm{Z}$ future business managers. They will very likely be comfortable in the virtual setting because of their acculturation, yet they will also be responsible for building and fostering the trusting relationships they value. This challenge creates an opportunity for higher education educators to utilize social media as part of team-based assignment criteria.

Generation $\mathrm{Z}$ also brings their technological savvy to campus. The tech-savvy generation expects use of this technology in the classroom. Professors may need to design course work that infuses more virtual connectivity.

It's crucial that Gen $\mathrm{Z}$ educators are current with up-to-date online and technology resources. Additionally, they need to "create connections" for the students (O'Connell, 2013). Medina (2008) has found that individuals who have used high speed technology during their formative years have shorter attention spans. He recommends that the teacher should respond to this Generation $\mathrm{Z}$ trait and divide class time into shorter, 10-minute segments. Each of these segments should be followed by a short "connector" such as a practical example of the materials' application, a short small-group exercise, or a "technology break" in which the students are encouraged to use their technology to research data, so on. It has also been noted that, "a short attention span, perhaps brought on by the tendency to multitask, also requires information to be delivered in rapid, short bursts if it is to be understood. Generation $\mathrm{Z}$ thrives on instant gratification" (quoted in Mueller, 2011). Furthermore, Abramovich (2015) cites a finding that the average Gen Zer's attention span is approximately eight seconds (para. 10). Therefore, perhaps the "chunks" of content will need to become shorter in the future. These neurological, psychological findings may lead to the need for faculty professional development endeavors. The campus where this manuscript's research occurred has instituted that type of training to facilitate faculty's comfort with effectively educating Generation Z. Vander $\operatorname{Ark}(2011)$ encourages a blend of online and onsite learning.

As stated previously, Phase 2 of this research involves face-to-face interviews within faculty and staff who interact with Generation Z college students. This phase is in its early stage of development. One interviewee thought that Generation $\mathrm{Z}$ students trust others too much and depend on social media to learn opinions rather than forming, and then trusting, their own ideas. This is supported by Renfro $(2012, a)$ who noted that they love to "crowd source" for 
solutions on social media. If the interviewed professor is accurate, how can professors develop the students' idea generation abilities and their self-efficacy of this competency?

Since Generation Z uses social media so much, it may help them transition easily into business professionals who use social media as a business tool. Therefore, professors, who, over the last few years, have been implementing high-tech tools in the classroom, will very likely be expected to add more assignments using a variety of social media platforms. As Wellner (2000) notes, Gen Z may be computer literate before they even get to [elementary] school...Multimedia will be as prevalent in the classroom as the chalkboard, (para. 4). The faculty will institute these actions as pedagogical tools while maintaining academic integrity. For content-heavy courses, this infusion of technology may be a challenge because of the time taken in class for social media interaction.

\section{LIMITATIONS AND AREAS FOR FUTURE DEVELOPMENT}

As noted earlier, there is a dearth of academic literature on this subject for higher education. The first phase of the research gained significant data for this research. One limitation is that the information is self-reported data and is centered in the Unites States. Most of the surveys were administered during class time, but the completion of the questionnaire was optional. Since most students have iPads or Macs in the classes, a person's self-selection out of the survey would not be visible. (The student who might elect not to participate could continue to use the devise for non-research activities.) Furthermore, a limitation of this study is that it was performed in high-tech university.

The sample size is limited. This manuscript reports student results conducted this year. A previous, current sampling of student surveys will be fused with this 2015 data and analyzed in the future. That will enlarge the number of participants. Furthermore, considering the precaution of Singham (2009), "stereotypes are of little use in predicting the traits that any given person is likely to display" (para. 15), the information contained in this survey is reflecting normative data of this research, and not intended to generalize nor stereotype.

Since this is a longitudinal, multi-phase study, the results and analysis have been expanded beyond the current convenience sample group. Those most recent results are noted in this documents. Future research will compare earlier student findings with the most recent results. The second phase of the research, face-to-face interviews with faculty and university administrative staff that teach and/or interact with Generation $\mathrm{Z}$ has begun. As this phase evolves, there may be continued agreement with the students' perceptions of various aspects. Furthermore, since the faculty will be from business and liberal arts courses, the type of topics covered in classes may influence the professors' perceptions of students' trust of others. As individual professors use technology in the classroom to varying degrees, will their impressions of this generation's use of social media differ? The online surveying of faculty stage of Phase 2 has been conducted with interesting results. Faculty from this convenience sample will be interviewed face-to-face to uncover some of their experiences that may have influenced their perceptions.

As Generation Z progress into higher college years, the survey size will be larger and may lead to differing results. Furthermore, additional mechanisms to operationalize and monitor Generations Z's college usage of social media and the outcomes of that usage may emerge. As different social media platforms and networks develop, research of this generation's use of this type of technology will need to determine how the possible introduction and use of new social media platforms impacts the emerging data for an investigation. 
Possible future research may lead to investigating how trust of others translates into an academic setting for these college students. How is trust established between professors and Generation Z?

\section{SUMMARY AND CONCLUSIONS}

Although demographers, marketers, and psychologists have discussed Generation $\mathrm{Z}$ in general interest publications and the popular press, very little scholarly research has been conducted about this group as 4-year, higher education students. This research found that Generation $\mathrm{Z}$ expect trust and truthfulness from those with whom they interact. They extensively connect with others through social media. They perceive themselves dependent upon this technology. They see themselves as flexible and adaptable.

The information offered in this research provides valuable information for an audience of higher education professors as well as professionals who investigate the pedagogical ramifications of teaching Generation Z. This study contributes to higher education pedagogy by providing a format for investigating students' perceptions of their use of social media, trust of others, and their adaptability.

The awareness of this student-centered information can enlighten a professor about the technology usage of students. As universities and colleges continue to realize the importance of students' perceptions towards trust and social media, these findings are relevant. The recent entrance of Generation $\mathrm{Z}$ into higher education leads to a need for more knowledge and understanding of student perceptions of various variables that may impact higher education. Therefore, the research findings delineated in this paper partially fill a gap in the academic literature.

\section{References}

Abramovich, G (2015, June 12). 15 Mind-Blowing Stats About Generation Z.CMO.com.

Anderson, J. (2004). Educating Generation Zzz ... Phi Kappa Phi Forum, 84 (4), p59-60.

Benhamou, L. (2015, February 11). Generation Z: Born in the digital age. In Yahoo News, at

http://news.yahoo.com/generation-z-born-digital-age-160347762.html

Bernstein, R. ( 2015, January 21). Move Over Millennials -- Here Comes Gen Z: What Marketers Need to Know About the Next Generation of Consumers. Advertising Age, at http://adage.com/article/cmo-strategy/movemillennials-gen-z/296577/

Crappell, C. (2013, August, September. ) Preparing Gen Z Students for Effective Practice. The ABCs of Gen X,Y(P), Z. American Music Teacher. Indiana University Press.

Dillon, N. (2007, September). Education Generation Z: What will the graduate of 2020 look like? Take a virtual peek into the future. American School Board Journal. Pp 35-36.

Elmore, T. ( 2014, October 15). Contrasting Generation Y and Z. HuffPost: Parents, at http://www.huffingtonpost.com/tim-elmore/contrasting-generation-y- b 5679434.html

Friedman, T. (2007, October 10). Generation Q. New York Times.

Fudin, S. ( 2012, March 29). Gen Z \& What it means in your classroom. USC Rossier Online.

Generation Z- "The iGeneration”. (2008, May 27). Retrieved from "The Employee Factor" http://www.employeefactor.com/?p=275

Garff, M (2011). The Virtual reality. T\&D: Issue August.

Geck, C. (2006, Feb.). The generation Z connection: teaching information literacy to the newest net generation. Teacher Librarian, Vol. 333, Issues 3.

Glum, J. (2015, Jan 13). Marketing to Generation Z: Millennials Move Aside as Brands Shift Focus to Under-18 Customers. International Business News. 
Higginbottom, K. (2013, April 22). Employees 3.0: Managing Generation Z. Edge Online

Hoffman, T. (2003). Preparing Generation Z. Computerworld, 37(34).

Lauzon, E. (2010, April, May). Are you ready for generation Z? Enterprise Innovation, Vol. 6, Issue 2, p. 44.

Lyon, E. (2010, February 23). Examining Generation Z: Stats, Demographics, Segments, Predictions. Retrieved from Sparxoo Agency, at http://sparxoo.com/2010/02/23/examining-generation-z-stats-demographics-segmentspredictions/

Malat, L. (2016, January 7). Gen Z is about to take over higher education-here's what to expect. eCampus News.

Markelein, M.B. (2012, January 26). Today's college freshmen hitting books harder, study says. USA Today.

McGirt, E. (2012). How ya like me now? Fast Company, Issue 164.

Medina, J. (2008). Brain Rules. Washington, Seattle: Pear Press

Micoleta, J. (2012, March 6). Generation Z Teens Stereotyped As 'Lazy And Unaware', Huffington Post, at http://www.huffingtonpost.com/2012/03/06/apathetic-teens-generatio_n_1323577.html

Mueller, J. (2011, March 13). Generation Z Characteristics. Retrieved from eHow.com

O'Brien, M. (2011). Defining the New Retail Experience. Progressive Grocer, 90(6).

O’Connell, J. (2013, July 19). TES: Times Educational Supplement. Issues 5053, p. 40-41.

Renfro, A. (2012, a). Meet Generation Z. http: gettingsmart.com/2012/12/meeting generation-z/

Renfro, A. (2012, b). Generation Z: The Biggest cheaters since Homer. Getting Smart

Singham, M. (2009). More Than 'Millennials': Colleges Must Look Beyond Generational Stereotypes. Chronicle Of Higher Education, 56(8), A104.

Seton Hill University. Retrieved at http://www.setonhill.edu/academics/mobile_learning

Slavin, A. (2014, November 16). Brand Strategy for a New Generation. Huffington Post

Smith, L. E. (2012). Do You Know Generation Z? Marketing, 12-13.

n.a. (2015, February). Stats Watch. New Wave of Students Wants to Design Own College Plan. University Business. Stone, B. (2010, January 9). The Children of Cyberspace: Old Fogies by Their 20s. The New York Times: Week in Review.

Thomas, W. “Gen Z?" in the X Zone (August 10, 1999) in Howe and Strauss, Millennials Rising, 2000 http://www.elderlyjournal.com/generation/generation-z/Characteristics-Of-Generation-Z.html

Vander Ark, T. (2011). Getting Smart: How Digital Learing is Changing the World. Jossey-Bass.

Wellner, A. S. (2000). Generation Z. American Demographics, 22 (9).

Williams, A. (2015, September 18). Move, Over, Millennials, Here Comes Generation Z. New York Times. 